\title{
A survey analysis of the wood pellet industry in Finland: Future perspectives
}

\author{
Svetlana Proskurina $^{\mathrm{a}^{*}}$, Eija Alakangas ${ }^{\mathrm{b}}$, Jussi Heinimö ${ }^{\mathrm{c}}$, Mirja Mikkilä ${ }^{\mathrm{a}}$ \& Esa Vakkilainen ${ }^{\mathrm{a}}$ \\ ${ }^{a}$ Lappeenranta University of Technology, Skinnarilankatu 34, 53850 Lappeenranta, Finland \\ ${ }^{\mathrm{b}}$ VTT Technical Research Center of Finland Ltd, Jyväskylä, Finland \\ ${ }^{c}$ Mikkeli Development Miksei Ltd, Mikkeli, Finland \\ * Corresponding author. Tel.: +358 466322953. \\ E-mail addresses: svetlana.proskurina@lut.fi, proskurina.s@mail.ru (S. Proskurina). \\ Postal address: Skinnarilankatu 34, FI-53850 Lappeenranta, Finland.
}

\begin{abstract}
Finland has the greatest forest cover of western European countries and thus considerable raw material potential for wood pellet market development. Wood pellet production and consumption volumes in the country have increased steadily during the last decades. The aim of this paper is to present an overview of the current status of the Finnish wood pellet business and discuss the main opportunities and challenges facing future development of the industry. The paper collects and revises data on the Finnish wood pellet market based on the results of a survey of nearly 60 wood pellet experts. The results show that neglect of policy support and a lack of suitable regulation are the key factors inhibiting Finnish wood pellet industry development. Currently, wood pellets are not economically competitive with other fuels. However, Finnish wood pellet markets seem promising if challenges such as high raw material costs and competitiveness with other fuels, especially for household users, are addressed. The country has the potential to become a more important producer and consumer on European wood pellet markets if effective policy support and a suitable regulatory framework are formulated.
\end{abstract}

Keyword: Pellets; market; Finland; bioenergy; power energy; biomass 


\section{Introduction}

Growing demand for $\mathrm{CO}_{2}$-free energy, concerns around environmental sustainability, and a desire to decrease dependence on fossil fuels are increasing the role of biomass in energy production. Finland is one of the leading countries in the European Union (EU) in terms of bioenergy utilization and, primarily due to the large share of biomass-based energy in the energy mix, Finland reached a 39\% share of renewable energy in final energy consumption in 2014 [1]. The country has plans of reaching 100\% renewables by 2050 [2]. Achieving this target is not easy and requires efficient technologies, especially for bioenergy, as this form of energy will likely provide the backbone of energy for transport.

Discussing a $100 \%$ renewable energy economy, Mathiesen et al. [3] present a Smart Energy Systems concept that may provide a more feasible energy economy structure and enable more sustainable use of bioenergy than current approaches. For Denmark, for example, an overall energy system analysis of a 100\% renewable energy system and an energy economy model based on linear programming for the optimal sizing of $100 \%$ renewable supply systems are presented by Lund and Mathiesen [4] and Milan et al. [5] respectively. 100\% renewable energy system scenarios have also been presented for Japan [6], Macedonia [7] and Portugal [8]. Describing existing studies on $100 \%$ renewable energy systems, Olabi [9] concluded that despite major progress in the field, more research and development are required if te aim of $100 \%$ renewable energy by 2050 is to be achieved.

Bioenergy will clearly play an important role in many EU countries, including Finland, in any $100 \%$ renewable energy future. Biomass is a variable and complex material with considerable challenges when used directly, i.e. in raw form, for energy production. When refined, however, solid biomass has energy density several times higher than untreated raw biomass and exhibits good flowability in various handling systems and logistics processes. Consequently, the biobased economy of the future can benefit from widespread adoption of densified solid biofuels, such as pellets, that can be efficiently handled, stored, and transported, and thus traded as a worldwide commodity [10].

Wood pellets are a climate-friendly fuel compared with fossil fuels. Sikkema et al. [11] showed that 12.6 million tons of $\mathrm{CO}_{2}$ eq emissions were avoided by using 8.2 million tons of wood pellets in 2008 in EU- 27 plus Norway and Switzerland. Compared with other biomass fuels, wood pellets have low moisture content and relatively high heating value [12]. Describing the benefits of wood pellet use in Italian CHP, Giacomo and Taglieri [13] noted that wood chips are mostly used locally, whereas the characteristics of wood pellets (Table 1) mean that they are not restricted to local use and are suitable, for instance, for use in urban areas and large public buildings. Pellets have smaller volume and higher volumetric energy density than raw wood, which makes storage, shipping and conversion into energy more efficient [14]. In addition, wood pellets usage generates more local employment than direct combustion of woody biomass [15].

The process of pellet production starts with storage facilities for the feedstock and forwarding of the wet feedstock to a dryer, as reduction down to $10 \%$ water content is required. Relative temperature, air humidity, particle size of the feedstock and drying technology used are factors that impact on the energy demand for drying. After drying, the biomass material, other than sawdust, is chipped and/or ground to achieve the required particle size for pellet production. The particles are then pelletized, after which the pellets are forwarded to a counter stream cooler, and finally to a storage facility [17]. 
Table 1: Main characteristics of wood pellets and wood chips in Finland [16].

\begin{tabular}{lcc} 
& Wood pellets & Wood chips \\
\hline & $14.0-17.5 \mathrm{MJ} / \mathrm{kg}$ & $10-11.5 \mathrm{MJ} / \mathrm{kg}$ \\
Calorific power & $4.7-5.0 \mathrm{kWh} / \mathrm{kg}$ & $3.5-4 \mathrm{kWh} / \mathrm{kg}$ \\
& $3100 \mathrm{kWh} / \mathrm{m}^{3}$ & $770 \mathrm{kWh} / \mathrm{m}^{3}$ \\
Water & $6-10 \%$ & $30-40 \%$ \\
Apparent density & $560-690 \mathrm{~kg} / \mathrm{m}^{3}$ & $250 \mathrm{~kg} / \mathrm{m}^{3}$ \\
Ashes content & $<0.7 \%$ & $<1.5 \mathrm{w}-\%$ \\
\hline
\end{tabular}

Using the example of wood pellet production in an Italian factory, Laschi [18] asserts that wood pellet production can have very low environmental impact, and presents scenarios to reduce impacts related to electricity demand for pellet production. Uslu et al. [14] state that pelletisation produces a uniform and stable fuel in which also the amount of dust produced is minimised. An additional advantage of pelletisation is that it enables free flowing of biomass, which facilitates material handling and aids flow control, which are important for loading and unloading operations.

Quality certification and standardisation of wood pellets is very fragmentary, and there are many different national wood pellet-related standards. A description of the wood pellet standards used in Europe in the period 2006-2012 was presented by Duca et al. [19]. Ståhl and Fredrik [20] suggest that many problems related to wood pellet usage can be avoided by modifying and harmonising national standards. Currently, the International Organisation for Standardisation (ISO) is preparing almost 60 standards for solid biofuels. Standards for pellets include: EN ISO 17225-1 (General requirements), EN ISO 17225-2 (Graded wood pellets) and EN ISO 17225-6 (Graded non-woody graded pellets). EN ISO 17225 series were published in May 2014 and also include product standards for wood chips, firewood and non-woody briquettes. The ISO standard EN ISO 17225-1:2014 includes a raw material classification of solid biofuels based on their origin and source. Stating the origin and source is mandatory for all solid biofuels [21]. International standard (EN ISO 17225-2:2014) for graded wood pellets includes pellets for industrial and non-industrial use. Biomass pellets in EN ISO 17225-1:2014 and industrial wood pellets in EN ISO 17225-2:2014 also include property classes for particle size distribution for disintegrated pellets. This value is important when pellets are co-fired with coal in pulverized combustion plants. Specifications for wood pellets for non-industrial use are given in EN ISO 17225-2:2014. Non-industrial use means fuel intended to be used in smaller appliances such as those found in households and small commercial and public sector buildings. EN ISO 17225-2 identifies non-industrial use wood pellets according to different classes. Property class A1 for wood pellets represents virgin woods and chemically untreated wood residues low in ash and nitrogen content. Fuels with slightly higher ash content and nitrogen content fall within property class A2. In property class B, chemically treated industrial wood byproducts and residues (1.2.2), and chemically untreated used wood (1.3.1) is also permissible, if threshold values for heavy metals can be met. The ENplus certification system is based on EN ISO 17225-2:2014 standard and ENplus certification ensures pellet quality, quality of service and sustainability. In total 6.5 million tons were certified by 180 certified producers and 250 traders [22].

The advantages that wood pellets provide mean that pellets have become a promising and stable commodity on biomass markets, and the wood pellet market is one of the most 
dynamically developing biofuels markets. Recently, there has been increased interest in wood pellet use in the EU, which offers subsidies for wood-fired heat and power plants and wood with coal co-fired power plants [24]. Total wood pellet consumption in the EU was 18.8 million tons in 2014. Italy, Germany, Sweden, France and Austria are the biggest wood pellet users in the EU [25]. In Italy, wood pellets are used mainly for heating in the residential sector, and consumption of wood pellets increased considerably after high sales of pellet stoves [25]. The biggest producers of wood pellets are Germany, Sweden, Latvia, France and Portugal [26]. In view of its potential as a source of easily-available bioenergy and the structure of demand elsewhere in Europe, wood pellet use should be promoted in countries with biomass potential.

European wood pellet markets with focus on the current status and prospects for 2020 have been discussed by Sikkema [27]. Presenting a structure market model for wood pellets in Austria, Kristöfel et al. [28] conclude that the pellet price is a decisive factor for further market development. Describing the role of wood pellets in the wood fuel market in Denmark, Olsson and Hilliring conclude that prices of wood pellets and wood chips do not follow a common trend [29].

In Finland, wood pellets are locally produced and distributed to domestic markets [25]. Although Finland has a long tradition of biomass utilization for energy production, wood pellet use is relatively new, and the domestic market is still in the development stage. Forest biomass is the most significant energy source in Finland, where use of wood energy is $25 \%$ of final energy consumption [30]. Additionally, woody biomass usage in liquid transportation fuels is increasing. It is expected that bioenergy will remain the backbone of renewable energy sources (RES) in Finland in the near future, and it has potential to provide $31-37 \%$ of primary energy consumption [31]. Although Finland has a long history of the use of wood as a fuel and has world-leading expertise in the forest industry and forest industry products, the country is not a leader in wood pellet utilization and production. Other European countries such as Sweden and Germany have more developed wood pellet markets [32].

A number of studies have examined the characteristics of European wood pellet markets and the status of wood pellet production and market development in Finland. Mola-Yudego et al. [33] studied wood pellet production in the European region and defined Finland as one of the main production areas of wood pellets in the EU. Describing Finnish wood pellet markets, Selkimäki et al. [34] concluded that Finland has significant scope not only to increase production, but also to increase consumption. Judl et al. [35] studied the issue of wood pellet use replacing fossil fuels in combined heat and power (CHP) and heat production in Helsinki. Their study concluded that burning wood pellets with coal, even with a low share (7\%), could be a step forward in reducing the emissions of greenhouse gases (GHG) from energy generation in the city of Helsinki. Heinimö et al. [36] presented a positive scenario for the international market for energy biomass by 2020, noting that half of respondents from the Finnish forest sector expect that the bioenergy sector, with the exception of the production and use of peat, will develop strongly, especially markets for wood pellets and forest chips. Describing wood fuels use in North Karelia, den Herder et al. [37] suggest that replacing oil with woody biomass in energy production would increase the local value added remaining in the region, create employment opportunities, and reduce total GHG emissions.

Recent research studies have to some extent neglected discussion of factors affecting future market development of the Finnish wood pellet market business. There is thus a need for updated information on the issue of future perspectives of the Finnish wood pellet industry and a need for up-to-date analysis of the main factors stimulating and inhibiting development of the Finnish 
wood pellet industry. A key question is why Finland, with its large biomass resource potential, is not a leader in EU wood pellet markets. This paper first presents an overview of the current status of the Finnish wood pellet business, then describes factors impacting the Finnish wood pellets industry, and discusses the main opportunities and challenges facing future development of the industry.

\section{Overview of the wood pellet industry in Finland}

The idea of "pelletisation" of wood biomass was first studied in Finland in the 1980s by Technical Research Centre of Finland (VTT). However, due to a drop in oil prices, and hence a lack of competitiveness, initial projects came to a standstill [38]. The production of wood pellets started in Finland in 1998, when the first pellet plant was built in Vörå, Ostrobothnia [39]. Figure 1 shows the development of wood pellet production, domestic consumption, and wood pellet import and export in Finland in 2001-2015.

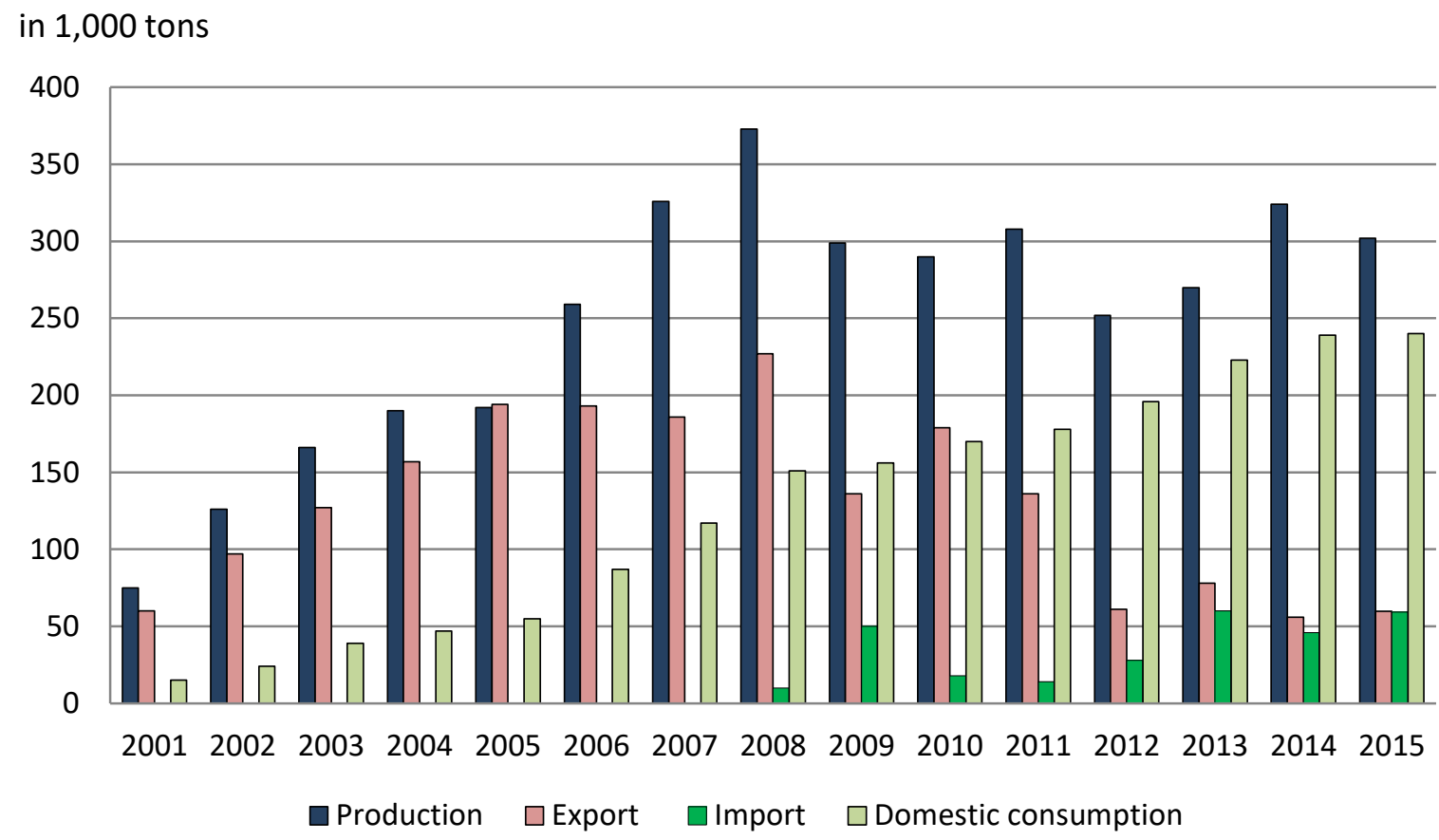

Figure 1: Wood pellet production, domestic consumption, and wood pellet import and export in Finland in 20012015, in 1,000 tons [40].

At present, approximately 25 wood pellet mills are in operation in Finland [41]. The main wood pellet production plants are located principally in the southern half of the country, where the greatest concentration of forest industry facilities is located (Figure 2). 


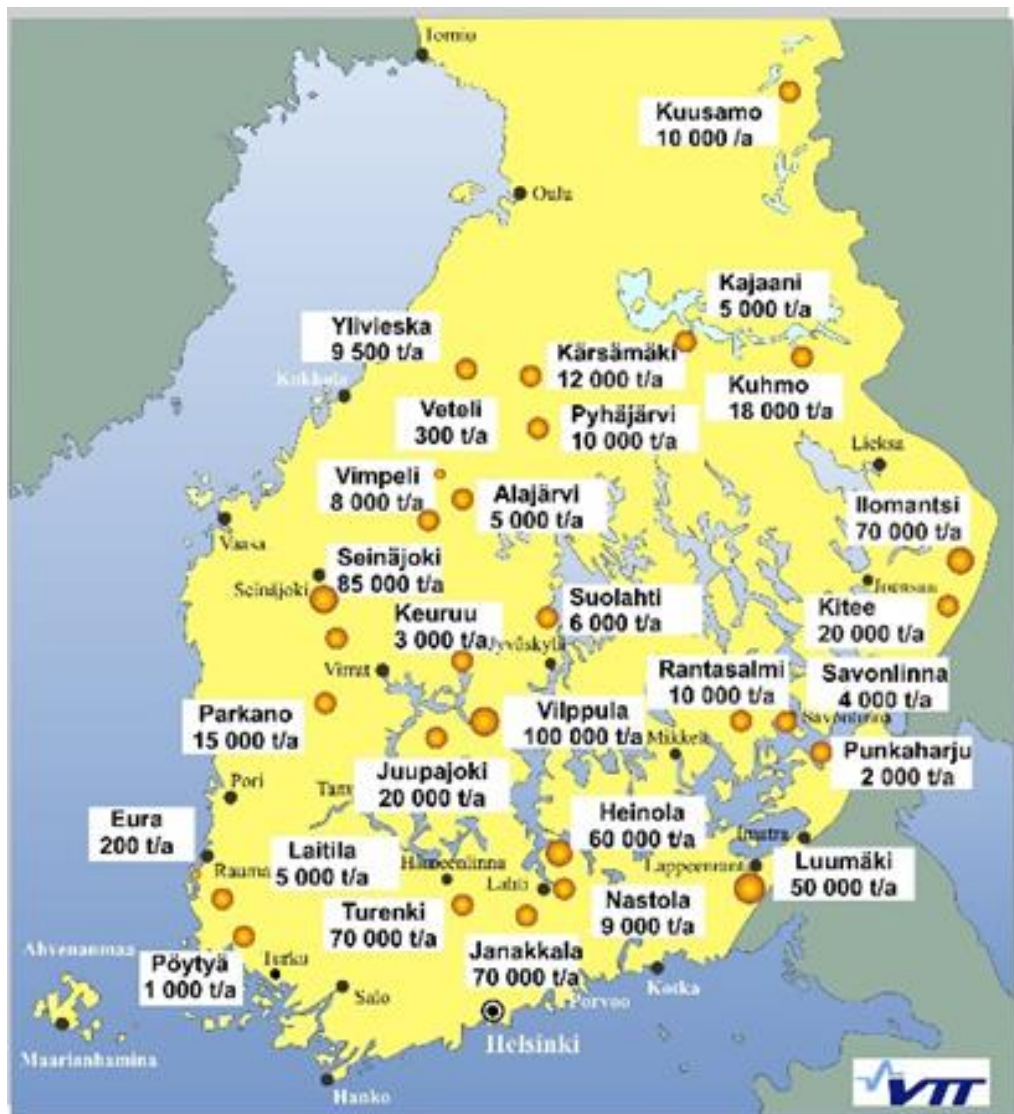

Figure 2: Main Finnish wood pellet producers and their capacities in tons in 2014 [42].

Vapo Oy, a partly state-owned publicly unlisted company, is the leader in wood pellet production in Finland, and the biggest producer in the Baltic Sea region. In 2013, Vapo supplied a total of 160,000 tons of pellets to the Finnish market, approximately 30,000 tons of which were delivered to households [43]. In 2014, the volume of wood pellets sold on Finnish markets decreased a little due to an exceptionally warm winter season, and all pellet producers, including Vapo, were left holding large stocks of pellets.

Denmark and Sweden are major consumers of wood pellets from Finland. Import of wood pellets into Finland is mainly from Russia (Figure 3) [44]. The decrease in wood pellet exports in 2014 can be explained by strategic changes by Vapo Oy, which refocused its operations exclusively on the domestic market. 
in 1,000 tons

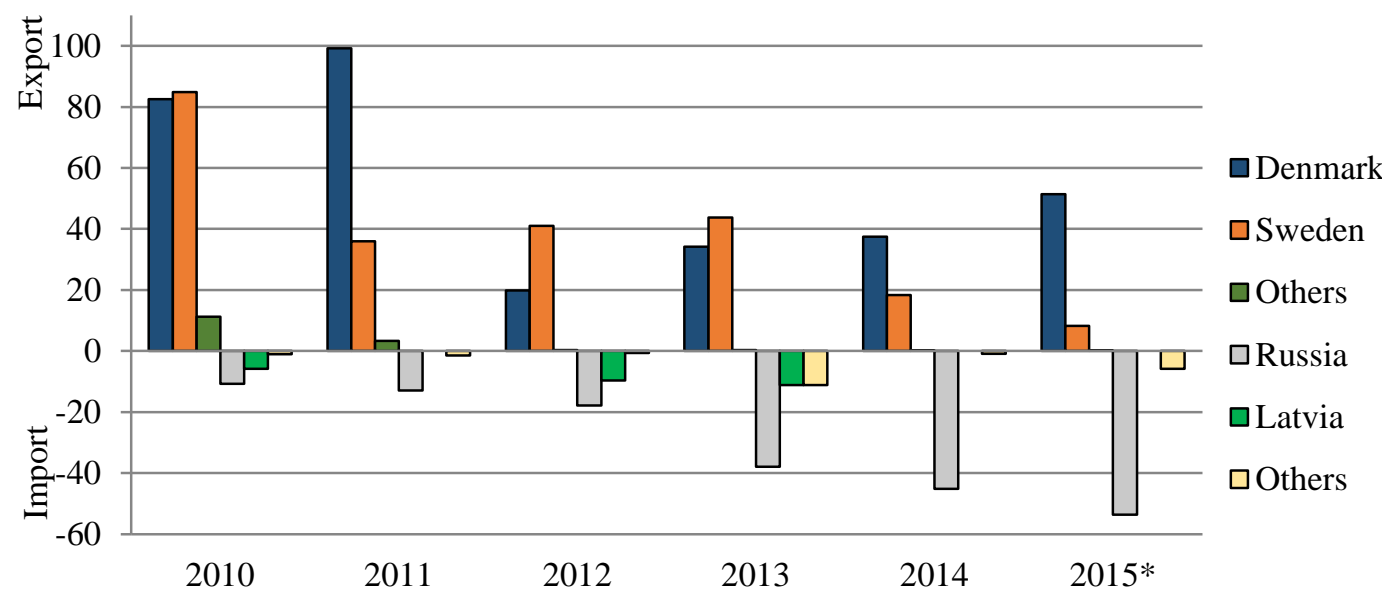

*preliminary

Figure 3: Export and import of wood pellets from and to Finland in 2010-2015 (in 1,000 tons) [45].

As can be seen in the figure, import and export of wood pellets is not large, and Finnish wood pellet producers mainly supply domestic users. Domestic consumption has increased in recent years, and it is possible to envisage changes in the export/import balance. Any significant increase in Finnish wood pellet consumption will likely be due to the commissioning and operation of large-scale applications. In the near future, the use of wood pellets in medium size boilers and for CHP also seems very promising, and several power companies have expressed interest in beginning usage and/or increasing existing usage of wood pellets. For households, the use of wood pellets is cheaper than oil but most households are not ready to invest in wood pellet heating systems.

Cofiring of wood pellets with coal has been tested in the Hanasaari and Salmisaari power plants, which are old CHP plants in Helsinki. The test results indicated the possibility of burning 5-7\% wood pellets in coal-based fuel without having to make major modifications to the grinders or burners. In 2015, Helsinki City Council, the owner of Helsingin Energia, agreed to meet energy demand for wood pellets in the Hanasaari and Salmisaari power plants. The delivery amounts are significant on the Finnish scale, in excess of 0.5 million tons/yr of pellets [46]. Another example of large-scale wood pellet use is a 33 MW capacity heating plant in Tampere, owned by Tampereen Energiantuotanto Oy, which has used wood pellets since December 2012. In addition, pellets will be used in Turku Energia's $40 \mathrm{MW}$ pellet boiler, which has been recently ordered for similar duty as the Tampere boiler [44]. Table 2 lists pellet-fired heating plants in Finland.

Table 2: Wood pellet-fired heating plants in Finland (Table prepared by VTT [47] with Finnish Bioenergy Association [48]).

\begin{tabular}{lclclc}
\multicolumn{1}{c}{ Plant } & MW $_{\text {th }}$ & \multicolumn{1}{c}{ Plant } & MW $_{\text {th }}$ & \multicolumn{1}{c}{ Plant } & MW $_{\text {th }}$ \\
\hline Nokia Tyres, Versowood & 1 & Parma Betoni, Äänekoski & 1 & $\begin{array}{l}\text { Savon Voima, } \\
\text { Lapinlahti }\end{array}$ & 7 \\
Halesa Oy, Nokia & 1 & Keuruu Heat Power & 1 & Raahe Energy & 10 \\
$\begin{array}{l}\text { Kirkkonummi, building } \\
\text { centre }\end{array}$ & 1 & Ypäjä municipality & 1 & Forssa Heat, Vapo & 10 \\
$\begin{array}{l}\text { Akaa, flat houses } \\
\text { Eerikkälä, sport park, Vapo }\end{array}$ & 1 & Mariehamn Energi & 1 & Hyvinkää Heat & $10^{*}$ \\
Nuutajärvi, Vapo & 1 & Savon Voima, Sorsakoski & 1.5 & Tampere Energy ${ }^{* *}$ & 33
\end{tabular}




\begin{tabular}{lclclc} 
Tammela, Vapo & 1 & Muurame industrial park & 2.5 & Kalajoki city & 4 \\
Vehmersalmi, Vapo & 1 & Leppäkoski heat, Ikaalinen & 3 & Fortum Kivenlahti & 60 \\
Kylmäkoski prison, Vapo & 1 & Parikkala municipality & 3 & Turun Energy & 40 \\
Vilppula, prison, Vapo & 1 & Paimio heat station & 4.5 & Kajaani Power & 10 \\
Valkeakoski Energy & 1 & Leppäkoski heat, Nokia & 6 & Seinäjoki Energy & $80-$ \\
\hline
\end{tabular}

In Finland, raw material for wood pellets are mainly by-products and residues from the wood processing industry, such as dry sawdust (which has the biggest share, over half of the raw material volume), cutter shavings, wood chips, and fresh sawdust. In 2012, the production potential of wood pellets was 9-27 PJ (0.2-0.6 million tons/yr), while use was only 3 PJ (71,600 tons) [49]. The Finnish National Forest Programme [50] has set a target of increasing the use of indigenous wood resources for energy purposes and has presented recommendations and policy support advice how to meet this aim in a sustainable manner via improvements in the biological diversity of Finnish forests. South-East Finland has a significant amount of underexploited forest biomass resources, and this region has the largest growth potential for forest biomass [49]. Anttila et al. [51] estimate technical harvestable potential for forest residues (tops and branches) in Finland as 6.6 million $\mathrm{m} 3$ (47.5 PJ), if round wood harvesting is at the same average level as during 2008-2012. Potential for stumps is 7.1 million m3 (51 PJ). If round wood harvesting is at the maximum sustainable level, logging residue potential will be as much as 11.6 million $\mathrm{m}^{3}$ (83.5 PJ) and stumps 12.0 million $\mathrm{m}^{3}$ (86 PJ). Thinning wood harvestable potential will be $6.2-$ 10.4 million $\mathrm{m}^{3}$ (45-75 PJ) [51].

\section{Methods}

This analysis of the Finnish wood pellet industry was done using a qualitative approach. The study is based on literature reviews combined with the results of a questionnaire. The aim of the questionnaire was to collect information about the current status and future perspectives of the Finnish wood pellet industry. The survey was conducted via the Internet by means of the online Webropol software tool. The questionnaire was sent to experts from a number of different organisations who are familiar with the Finnish wood pellet industry and market. Driving forces were elicited by inquiring about the factors stimulating and inhibiting development of the Finnish wood pellet industry, for whom (consumer, producer, traders etc.) wood pellets are the more profitable business, and what the future expectations of the Finnish wood pellet industry might be.

Participants received the survey from 6 October to 18 November 2015 and a maximum of two follow-up emails, spaced 2 weeks apart, to encourage participation. The total number of experts who received or viewed the questionnaire is unknown. The questionnaire was sent to experts in different Finnish companies (such as Vapo, Stora Enso, Versowood etc.) and research organizations (such as LUKE'e VTT etc.) and was posted on the Finnish wood pellet forum (pellettiforum.fi), Russian bioenergy portal (infobio.ru) and Ukrainian Biofuel Portal (pelletswood.com), from which every registered expert could participate in the study. Additionally, several respondents shared the questionnaire with colleagues who are familiar with the Finnish wood pellet industry.

The questionnaire was primarily oriented to Finnish experts. However, experts from other countries having co-operation with Finland in wood pellet production and wood pellet markets were taken into consideration. The questionnaire contained thirteen different questions, including 
one open question and two partly open questions. Respondents had the possibility of replying anonymously. However, most respondents left personal contact information as they wished to receive a summary of the survey results by e-mail, indicating interest in the future of Finnish wood pellets. The results of this study consequently represent the opinions of 58 wood pellet experts from Finland and neighbouring countries. Figure 4 describes the key contents of the questionnaire.

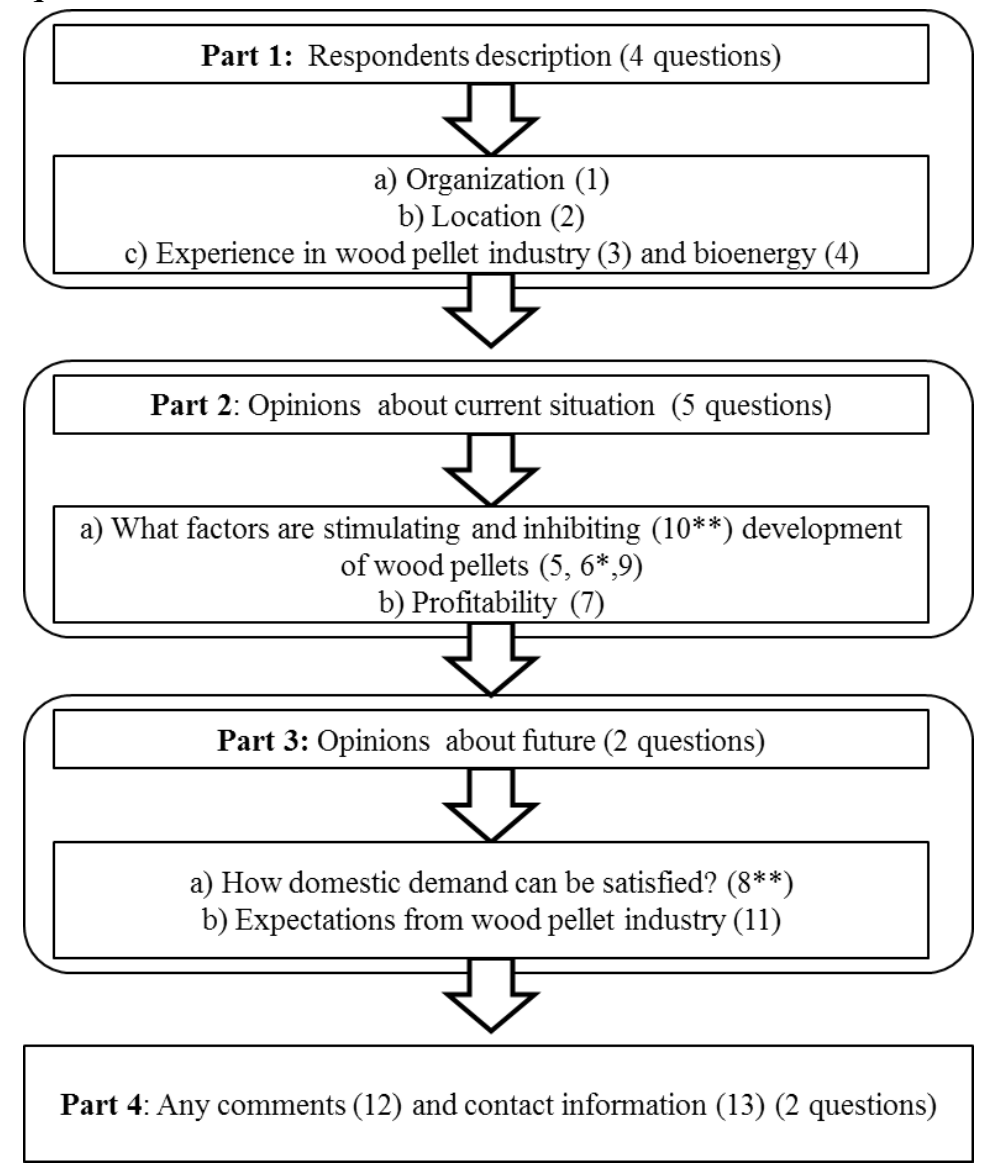

Figure 4: Key contents of the questionnaire. * open questions and ** partly open question.

The main advantages of the questionnaire approach used are as follows. Firstly, the respondents are very familiar with the Finnish wood pellet industry and so they possess valuable information that is not available, for example, in conventional literature. Secondly, the respondents' answers are given based on the current situation in the Finnish wood pellet industry, thus the results of the questionnaire reflect recent changes in the Finnish wood pellet industry and give a more realistic picture of the current situation.

Finally, the anonymity of the approach helps allay concerns about confidentiality and allows open discussion of the subject. Respondents from different organizations with different socialeconomic status within and outside of Finland make the survey results more comprehensive and representative of different perspectives. The results of the questionnaire are mainly presented in terms of percentiles.

In survey method approaches, interpretation of results and drawing of conclusions is nontrivial, which means that the validity, reliability and generalizability of the conclusions are sometimes not easily ensured [52]. To increase the reliability of the research, the first two questions were about the participants themselves and provided an overview of the background of the respondents and their familiarity with wood pellets and bioenergy in general. This information helped ensure the validity of the answers. The data collection method used can be considered 
accurate and reliable. Avoiding missing answers, all questions and answer options were compulsory.

The main disadvantages of the questionnaire approach used are as follows. Firstly, respondents are self- selected and may be motivated by self-interest. For example, respondents may be more oriented to gaining the results of the survey rather than giving honest answers. Despite the fact that the questions cover general issues and focus on opinions, corporate ethics may limit the scope for truthful answers. Most respondents are from organizations working in the field, and thus they may face confidentiality restrictions regarding the dissemination of sensitive industrial information that is available only within the organization. For example, Finland has many small and medium consumers and producers of wood pellets who may have competitivity concerns about participating in the survey. Additionally, respondents may lack understanding of the importance of the study and its impact on society. To try to avoid possible misunderstanding, respondents received information clarifying the context of the questionnaire and describing the aims of the study.

Secondly, as certain answer options may be interpreted differently by different respondents, the answer options of the survey questions could lead to unclear data. For example, the answer option "somewhat agree" may represent different things when referring to different subjects, and have its own meaning to each individual respondent. To avoid such problems, the survey includes different kinds of questions and has similar questions of different types related to similar (one) issues. To ensure accuracy each question was treated as if it was a tiny version of the test (and consistency was measured in that function). Thus, a series of questions are combined to give a picture of one complex concept about wood pellets industry.

Thirdly, timing plays an important role. The study mostly focuses on the year 2015 and changes such as a significant decrease in the fossil fuel price and its impact, as well as changes in the overall economic situation are not taken into consideration. Fourthly, regarding data analysis, due to the anonymity and lack of personal contact with the respondents, it is not possible to clarify any uncertainties. For example, in open questions, the comments of the respondents may be somewhat unclear and open to different interpretations. To mitigate this problem, the majority of the information was cross-checked through a literature review, i.e. the information was checked using different instruments. On the whole, the information supplied by the respondents seemed realistic and concurred with literature sources.

Finally, one of the greatest weaknesses of questionnaire-based approaches is that the views of respondents who choose to respond to a survey question may be different from those who choose not to respond, thus creating bias. As the respondents are self-selected and the survey was published in different places, the response rate of the questionnaire is difficult to evaluate. However, even if the response rate is known and it is possible to calculate mathematically possible maxima and minima and add error bars to graphical representation of the data, the range often becomes too wide to be reliable. To increase the response rate, and to provide a motivation for the respondents, respondents were informed that the survey results would be send to respondents who left contact information.

A further problematic aspect of the questionnaire approach can be the human factor. Responses about the future of Finnish wood pellet markets can depend on the mood of the respondents at the moment of answering. For example, respondents in a positive mood may be more optimistic about the Finnish wood pellet industry. Additionally, despite the fact that the survey was short and short answers were expected, most respondents have limited time, thus opinions may be poorly expressed or questions and/or response options misunderstood. The survey was written in 
English, which must be borne in mind, as despite the fact that the respondents had a good command of English, as witnessed by their responses to the open-ended question, possible interpretation errors due to language difficulties cannot be excluded.

The opinions about the wood pellet industry expressed by the different respondent groups mostly concurred. Cases where there are significant differences in opinion between the different groups are presented and examined in the discussion and results sections.

\section{Results and discussion}

This section of the paper presents and discusses the main results of the survey. First, the profile of the participants is described. Then, factors stimulating and inhibiting development of the Finnish wood pellet industry are discussed. Finally, challenges facing the Finnish wood pellet industry, the profitability of the Finnish wood pellet industry and future perspectives are examined.

\subsection{Participants}

Figure 5 categorizes the respondents based on the organization that they represent. The largest share of respondents belong to the category 'others'. Respondents in this category represented mainly various companies involved in the timber products business (such as round wood handling, solid biofuel trade, consulting, boiler supplier, boiler and heating plant manufacturing companies, a as well as a stevedoring company) and non-governmental organizations (NGOs) such as the Pellet Association, World Bioenergy Association and other interest groups, and independent experts. It should be noted that many of the respondents were from profit-driven organizations in the field.

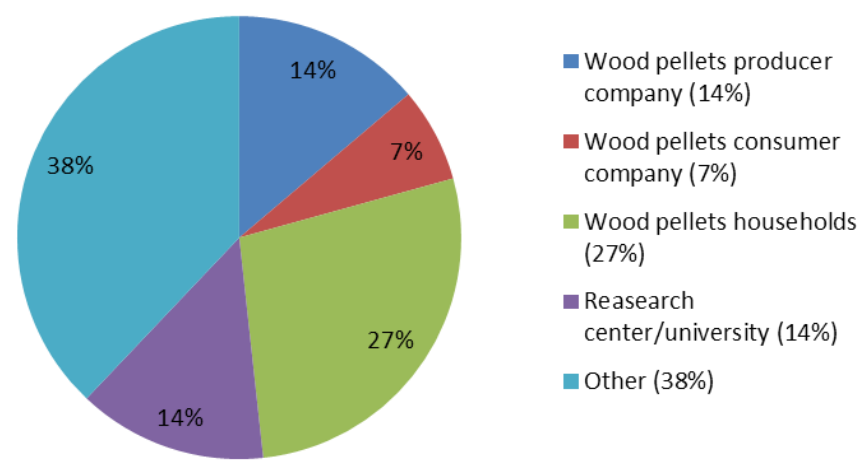

Figure 5: Organization represented by the respondents.

The majority of the respondents $(83 \%)$ were from Finland, with some respondents being from neighbouring countries (17\%). Figure 6 shows the experience of respondents in bioenergy and the wood pellet industry. 
A

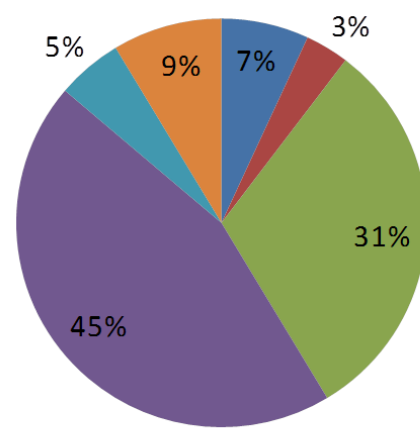

B

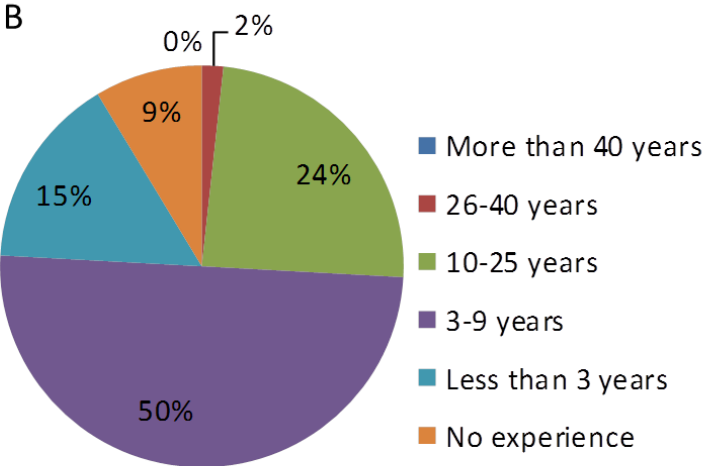

Figure 6: Respondents with experience in the bioenergy field (A) and wood pellet industry (B) (in and outside Finland).

\subsection{Factors stimulating and inhibiting development of the Finnish wood pellet industry}

Table 3 gives the opinions of the respondents concerning different factors that stimulate and inhibit development of the Finnish wood pellet industry, in absolute numbers of answers per question.

Table 3: Opinions of respondents.

\begin{tabular}{|c|c|c|c|c|c|c|}
\hline & $\begin{array}{c}\text { Strongly } \\
\text { agree }\end{array}$ & Agree & Neutral & Disagree & $\begin{array}{l}\text { Strongly } \\
\text { disagree }\end{array}$ & $\begin{array}{l}\text { Don't } \\
\text { know }\end{array}$ \\
\hline $\begin{array}{l}\text { The Finnish wood pellet industry is } \\
\text { environmentally friendly. (4.2.1) }\end{array}$ & 26 & 21 & 7 & 1 & 1 & 2 \\
\hline $\begin{array}{l}\text { The low price of fossil fuels is inhibiting } \\
\text { development of the Finnish wood pellet industry. } \\
(4.2 .2)\end{array}$ & 16 & 31 & 7 & 4 & 0 & 0 \\
\hline $\begin{array}{l}\text { In Finland, wood pellets compete with other } \\
\text { renewable fuels. (4.2.2) }\end{array}$ & 8 & 26 & 13 & 10 & 1 & 0 \\
\hline $\begin{array}{l}\text { Wood pellet standards are helping development of } \\
\text { the Finnish wood pellet industry. (4.2.3) }\end{array}$ & 7 & 30 & 11 & 5 & 0 & 5 \\
\hline $\begin{array}{l}\text { EU Renewable Energy (RE) targets are } \\
\text { stimulating development of the Finnish wood } \\
\text { pellet industry. (4.2.3) }\end{array}$ & 2 & 29 & 9 & 11 & 5 & 2 \\
\hline $\begin{array}{l}\text { Finnish national RE targets are stimulating } \\
\text { development of the Finnish wood pellet industry. } \\
(4.2 .3)\end{array}$ & 7 & 17 & 16 & 10 & 5 & 3 \\
\hline $\begin{array}{l}\text { The global wood pellet market is stimulating } \\
\text { development of the Finnish wood pellet industry. } \\
(4.2 .3)\end{array}$ & 4 & 19 & 15 & 12 & 5 & 3 \\
\hline $\begin{array}{l}\text { Finnish wood pellet production cost is higher than } \\
\text { European production cost. }(4.2 .4)\end{array}$ & 4 & 19 & 10 & 11 & 2 & 12 \\
\hline $\begin{array}{l}\text { Development of the Finnish wood pellet industry } \\
\text { is hindered by a lack of international co-operation. } \\
(4.2 .5)\end{array}$ & 7 & 13 & 17 & 12 & 4 & 5 \\
\hline $\begin{array}{l}\text { Recent political events (e.g. the ongoing conflict } \\
\text { in Ukraine) have reduced wood pellet imports } \\
\text { from Russia to Finland. (4.2.5) }\end{array}$ & 1 & 9 & 16 & 15 & 4 & 13 \\
\hline $\begin{array}{l}\text { Wood pellet logistics in Finland is } \\
\text { underdeveloped. }(4.2 .5)\end{array}$ & 13 & 15 & 16 & 8 & 2 & 4 \\
\hline
\end{tabular}




\subsubsection{Environmental aspects}

About $81 \%$ of respondents feel that the Finnish wood pellet industry is environmentally friendly in general. However, some aspects of the wood pellet industry bring challenges as regards environmental issues. Despite the advantages of wood pellet use in CHP plants, Judl et al. [35] note possible negative impacts on air quality due to the required truck transportation of the wood pellets. Presenting a sustainability impact assessment on the production and use of different wood and fossil fuels in North Karelia, Finland, Den Herder et al. [37] conclude that pellet production and combustion cause more GHG emissions (about $470 \mathrm{~kg} \mathrm{CO}_{2}$ eq./MWh) than the production of other solid biofuels such as wood chips and firewood (about $420 \mathrm{~kg} \mathrm{CO}_{2}$ eq./MWh). In their responses, respondents express concern about the effect of fossil fuel use on air quality and suggest that this issue could be partly addressed by increasing solid biofuels usage in Finland.

Environmental concerns may promote the change from fossil fuels to wood pellets; however, according to the respondents, emission limits, the absence of sufficiently high $\mathrm{CO}_{2}$ taxes and a sufficiently high price for EU emissions allowances $\left(\mathrm{CO}_{2}\right)$ inhibit the wood pellet industry in Finland. Emission limits and emission permit prices are not high for many industrial and energy generation plants in Finland, and reducing emission limits and increasing permit prices may motivate greater use of pellets. In general, environmental issues were mostly considered to stimulate the wood pellet industry rather than inhibit it (see also Section 4.3, Table 4).

\subsubsection{Competition of wood pellets with other fuels}

Most respondent agree that wood pellets compete with other renewable fuels. Most of the respondents believe that Finland has cheaper types of solid biofuel than wood pellets and that this is a major obstacle to development of industrial scale use of wood pellets. Wood chips are the most popular solid biofuel type and investments in boilers that are capable of utilising lower quality wood fuels are often preferred to investments in wood pellet equipment. Additionally, wood chips are easily available, and a large number of companies and entrepreneurs operate in Finnish wood chips markets.

Statistically, Finland is the second country in terms of wood chips consumption (9.4 million/yr) and in fourth place in terms of number of plants using wood chips (over 470) in the EU-28 [53]. Historically, the wood chips industry has shown stable growth, with 1.6 TWh (5.7 PJ) and 18 TWh (50 PJ) in 2000 and 2014 respectively, and wood chips usage is expected to continue to grow [54]. Finland aims to reach $24 \mathrm{TWh}(86 \mathrm{PJ})$ per year of forest chips for energy generation by 2020 , which is considered a realistic target [55]. When considering the competitiveness of wood pellets, internationalization of the wood pellet market introduces a host of price-affecting factors that are not shared by markets for wood chips [29].

More than $80 \%$ of respondents agreed that the currently low price of fossil fuels is inhibiting development of the Finnish wood pellet industry. In comments, many respondents suggest that increased taxation of fossil fuels, stricter emissions limits for heavy duty oil and higher prices for other fuels would stimulate development of the wood pellet industry. According to the respondents, the low price of electricity and oil, the high price of pellet use as heating fuel and difficulties with switching from fossil fuel to wood pellets, especially in rural areas, inhibit the Finnish wood pellet industry. In the residential market, wood pellets are not as popular as fossil fuels. One of the respondents noted that oil is preferable because when buying wood pellets the invoice requires immediate payment, while for heating oil the invoice can be paid in instalments. 
Another fuel with which wood pellets compete is peat. With increase in energy production in 1980-1990, the peat industry increased significantly. Since 2007, however, the use of peat for energy has begun to decline, although peat still plays an important role in energy production in Finland. In 2011, a total of 62,000 hectares of land was used for peat production, which is equal to around $0.7 \%$ of the total area of mires and peatlands in Finland. Over $90 \%$ of extracted peat is used for energy production. The Finnish government's 2013 National Energy and Climate Strategy calls for a reduction in the use of peat for energy by a third from the present annual average of $23 \mathrm{TWh}$ (83 PJ) by 2025. With a view to the next 10-20 years, the strategy assumes that at least 11-13 TWh (40-47 PJ) of heat energy will still be produced with peat, since peat cannot always be replaced with woodchips or other renewables. According to the strategy, peat should not be replaced with coal, even though peat producers report that this is often what occurs [56]. Despite the important role of peat in Finnish energy production, according to the respondents, the peat industry has no significant impact on Finnish wood pellet market development (see section 4.3, Table 4).

In comments given by the respondents, one opinion was expressed that increased use of solar panels may inhibit development of the wood pellet industry. Solar energy has become attractive in Finland, and several projects have come on stream in recent years. One respondent drew attention to the option of geothermal heating, which is used in small- and medium-scale heating and is cheaper and more user- friendly than wood pellets. In comparison with the low price of fossil fuel, competition from other renewable fuels is not particularly significant in terms of its inhibiting effects on the wood pellet industry. The goal of reaching $100 \%$ renewable energy requires development of all renewables and wood pellets cannot satisfy all the required energy need for the country.

\subsubsection{Policy support and wood pellet standards}

According to the respondents (Table 1), the EU's renewable energy targets [57] have a greater stimulus effect on the Finnish wood pellet industry than Finnish national RE targets and the global wood pellet market. In Finland, bioenergy has been subsidised through various energy policy tools such as research and development (R\&D) grants, investment grants, and energy taxation [58]. The Finnish National Renewable Energy Action Plan (NREAP) [58] has set a target for wood pellet use of increasing domestic consumption from the current $3 \mathrm{PJ} / \mathrm{yr}$ to 7.2 $\mathrm{PJ} / \mathrm{yr}$ (0.42 million tons) by 2020. Investments related to the use of pellets in renovated buildings will be subsidized with investment grants [59]. In 2014, Finland published "The Finnish Bioeconomy Strategy" [60], whose aim is to increase bioeconomy output to 100 billion euro by 2025 and to create 100,000 bioeconomy-related new jobs in Finland.

Despite these policy measures, most of the respondents suggest that the Finnish government has neglected support for the wood pellet industry, for example, compared with Sweden, where the government supports the wood pellet industry via an energy policy framework covering fuel taxation and subsidies [33]. Respondents mentioned that the Government of Finland is "indecisive" and uncertainty about taxation, subsidies and allowances hinders long-term investment planning and thus development of the market. One respondent states: "There is an urgent need to by taxation or other policy reforms to increase the price of competing fossil oil and residential users' electricity." In comments, some of the respondents mention a lack of support from the EU and the impact of global economic trends, which affect sawmilling volumes and, consequently, the wood pellet industry. Policy support is clearly a crucial factor for wood 
pellet industry development, as can be seen from the example of Italy, where policy support had a significant role in motivating households to adopt wood pellets.

On the subject of wood pellet standards, more than half of the respondents were of the opinion that wood pellet standards promote development of the Finnish wood pellet industry (Table 1). It is noteworthy that more than $70 \%$ of respondents with more than 10 years' experience in the Finnish wood pellet industry mentioned the beneficial effects of wood pellet standards. Some of the respondents noted situations where pellets of poor quality, which make burning difficult, had come onto the markets and damaged the reputation of pellets. Additionally, a lack of $6 \mathrm{~mm}$ pellet production was considered to be inhibiting development of the industry. About $50 \%$ respondents representing Finnish households agreed about the importance of wood pellet standards. Wood pellet standards can help not only the trade in wood pellets, but also improve the wood pellet industry development within the country.

\subsubsection{Local raw material and market price}

Many respondents note that wood pellet production costs in Finland are not higher than elsewhere in Europe. Describing the economics of the wood pellet business in several countries, including Finland Trømborg et al. [17] found that economic sustainability for European pellet producers depends to a large extent on domestic markets as internationally traded pellets, for example from the USA and Canada, are often priced below European production costs.

Although Finland has large biomass resources (section 2), respondents note that raw material is expensive. This can be explained by the fact that forest resources in Finland are used for many different purposes. Most of the forests in Finland are owned by private individuals, there are 350,000 private forest owners in Finland, and many owners tend not to optimize their financial returns but have other, non- monetary targets in their forest management.

Additional to the high cost of Finnish raw material, respondents note that the large number of different retailers that participate in the wood pellet supply chain increase the final price of wood pellets for consumers. According to respondents, the price of wood pellets has increased significantly during the last 10 years and cannot compete with other biofuels (Section 4.2.1). Additionally, pellet boilers are inflexible, being restricted to pellets, and the pellet market price in Finland too dependent on the prices of large wood pellet producers. One respondent using 140 tons of wood pellets annually in a machining factory suggested that large pellet producers are "inhibiting development by keeping prices high despite lowering trend of consumable and energy prices" and noted that a current price of 187 euros/ton is "too expensive to make new pellet boiler investment at the moment."

\subsubsection{Wood pellets logistic and international co-operation}

When considering the logistics of the Finnish wood pellet industry, some of the respondents suggest that Finland lacks infrastructure for long-distance supply chains, that transportation costs are too high, and that establishing the "right" connections (from manufacturer to the silo of the end user) and networks are necessary steps to improve development of the Finnish wood pellet industry. To minimize costs for transportation, most pellet plants are located near sawmills, furniture factories and other wood processing facilities. An example is pellet production in Kuhmo, where local raw material resources are the largest in the whole region of Kainuu. Many small- (with capacity under 5,000 tons) and medium-scale pellet plants (with capacity from 5,000 to 100,000 tons) are integrated with other activities such as planing mills or carpentry factories, which are the source of the raw material for pelletizing. 
As regards international cooperation, the Finnish wood pellet industry has good connections with other countries and Finnish operators have a solid reputation in the bioenergy field within and outside the EU. Many respondents believe that recent political events (conflict in Ukraine etc.) do not significantly affect the Finnish-Russian relationship in terms of the wood pellet industry. One respondent suggested that "Russians are waiting [expecting] more business profitability from the pellet exports to Finland than is realistic." This comment can be explained by differences in the business cultures; Russian investors tend to expect faster returns than Finnish investors, who mostly invest for the long-term.

Additionally, one opinion was expressed concerning bioenergy in general that cannot be left unmentioned: "Potential for development but anti-bioenergy propaganda from joint forces of NGOs and forest industry lobbyists in Brussels could stop development. Also, companies in the bioenergy business must understand that they cannot be sloppy with their sustainability work. If bioenergy is not viewed as a viable and sustainable alternative to fossil fuels, the market will disappear". Finland as a member of the EU is dependent on the development of bioenergy in the European region as a whole. Actions by other

EU countries in areas such as wood pellet technology, standards development, R\&D etc. impact greatly on the Finnish wood pellet industry and its prospects. Anti-bioenergy propaganda and skepticism regarding renewable fuels may become an external factor hindering the development of Finnish wood pellet industry.

\subsection{Challenges facing the Finnish wood pellet industry}

Respondents were asked to rank the main factors inhibiting Finnish wood pellet industry development in order of priority (Table 4). As can be seen, more than half of respondents suggest that a lack of policy support and a failure to implement a suitable regulatory framework are inhibiting Finnish wood pellet industry development. Despite existing bioenergy support via Finnish government policy, it is felt that additional measures should be taken to motivate the wood pellet industry to develop further (as noted in Section 4.2.3). Competition with other biofuels (discussed in Section 4.2.2) is another significant factor, and there is a need to make wood pellets more competitive with other biofuels in terms of price domestically and in terms of competitiveness on international markets. Lack of investment is a further key factor inhibiting Finnish wood pellet industry development. Respondents suggest that Finland needs to increase investments in pellet-boilers and increase private initiatives (see Section 4.2.4). A lack of raw material is not considered a major challenge, although as mentioned earlier (Section 4.2.4) it was felt that the cost of raw material should be lower. Only 3 respondents, all representing households, suggested a lack of $R \& D$ as the greatest factor inhibiting Finnish wood pellet market development. Allocating importance to a lack of R\&D was mainly found among household respondents, whereas wood pellet producers and consumers considered this factor to be less meaningful. The difference between the views of the two groups can be explained by the fact that generally R\&D in the wood pellet industry is well developed in Finland with many large bioenergy companies having their own research groups and close connections with universities and industrial research organizations. 
Table 4: Main factors inhibiting Finnish wood pellet industry development (in order of importance: 5=greatest importance, 4=considerable importance, 3=important, 2=less important, 1=least importance) (in number of respondents).

\begin{tabular}{lccccccc}
\hline & 5 & 4 & 3 & 2 & 1 & Don't know \\
\hline Lack of policy support and regulations. & 17 & 18 & 8 & 8 & 1 & 6 \\
Competition from other solid biomass, e.g. wood chips. & 9 & 18 & 13 & 11 & 3 & 4 \\
Lack of investment & 8 & 19 & 12 & 8 & 6 & 5 \\
\hline Lack of raw materials & 5 & 8 & 14 & 17 & 10 & 4 \\
Lack of R\&D & 3 & 9 & 19 & 8 & 12 & 7 \\
Peat industry & 1 & 11 & 15 & 12 & 12 & 7 \\
Environmental issues & 0 & 4 & 9 & 23 & 15 & 7 \\
Others & 3 & 6 & 5 & 1 & 0 & 23 \\
\hline
\end{tabular}

Discussion of environmental issues and the peat industry is presented in section 4.2.1 and 4.2.2 respectively. Additionally, respondents suggested other factors such as the "price of fossil fuels, expensive raw material and end user price, consumer guidance, strong wood log and oil heating tradition, economic downturn, the heat pump systems, marketing and lack of 'full service packages' for potential customers, poor pellet heating devices and market price between the parties" as factors impinging on Finnish wood pellet industry development.

\subsection{Profitability of the Finnish wood pellet industry}

Most of the respondents suggest that the wood pellet industry is a profitable business in Finland (Table 5). An interesting finding is that most of the Finnish wood pellet producers (55\%) believe that wood pellets are an unprofitable business for small and medium producers (Table 6). While $88 \%$ of them express that it is profitable for households. Finnish household users $(63 \%)$ also believe that wood pellets are more profitable for large consumers, with trading in wood pellets also viewed as profitable (Table 7). About 44\% of Finnish households' users agree that Finnish wood pellets are profitable for households.

Table 5: Respondents' opinions (58 responses) about the profitability of the Finnish wood pellet industry (in number of respondents).

\begin{tabular}{|c|c|c|c|c|c|c|}
\hline $\begin{array}{l}\text { Wood pellets are profitable business in Finland } \\
\text { for: }\end{array}$ & $\begin{array}{l}\text { Strongly } \\
\text { agree }\end{array}$ & Agree & Neutral & Disagree & $\begin{array}{l}\text { Strongly } \\
\text { disagree }\end{array}$ & $\begin{array}{l}\text { Don't } \\
\text { know }\end{array}$ \\
\hline Large-scale consumers (e.g. CHP plants). & 9 & 25 & 7 & 8 & 5 & 4 \\
\hline Households. & 3 & 30 & 9 & 7 & 5 & 4 \\
\hline Traders. & 3 & 25 & 14 & 5 & 3 & 8 \\
\hline $\begin{array}{l}\text { Small producers (less than } 100,000 \text { tons } \\
\text { capacity). }\end{array}$ & 3 & 22 & 9 & 12 & 3 & 9 \\
\hline $\begin{array}{l}\text { Large producers (over than } 100,000 \text { tons } \\
\text { capacity). }\end{array}$ & 5 & 27 & 8 & 7 & 2 & 9 \\
\hline
\end{tabular}

Table 6: Wood pellets producers' opinions (8 responses) about the profitability of the Finnish wood pellet industry (in number of respondents).

\begin{tabular}{lcccccc}
\hline $\begin{array}{l}\text { Wood pellets are profitable business in Finland } \\
\text { for: }\end{array}$ & $\begin{array}{c}\text { Strongly } \\
\text { agree }\end{array}$ & Agree & Neutral & Disagree & $\begin{array}{c}\text { Strongly } \\
\text { disagree }\end{array}$ & $\begin{array}{c}\text { Don't } \\
\text { know }\end{array}$ \\
\hline $\begin{array}{l}\text { Large-scale consumers (e.g. CHP plants). } \\
\text { Households. }\end{array}$ & 3 & 4 & 1 & 0 & 0 & 0 \\
$\begin{array}{l}\text { Traders. } \\
\begin{array}{l}\text { Small producers (less than 100 000 tons } \\
\text { capacity). }\end{array}\end{array}$ & 0 & 3 & 2 & 2 & 1 & 0 \\
$\begin{array}{l}\text { Large producers (over than 100 000 tons } \\
\text { capacity). }\end{array}$ & 0 & 3 & 1 & 3 & 1 & 0 \\
\hline
\end{tabular}


Table 7: Finnish households' opinions (16 responses) about the profitability of the Finnish wood pellet industry (in number of respondents).

\begin{tabular}{|c|c|c|c|c|c|c|}
\hline $\begin{array}{l}\text { Wood pellets are profitable business in Finland } \\
\text { for: }\end{array}$ & $\begin{array}{l}\text { Strongly } \\
\text { agree }\end{array}$ & Agree & Neutral & Disagree & $\begin{array}{l}\text { Strongly } \\
\text { disagree }\end{array}$ & $\begin{array}{l}\text { Don't } \\
\text { know }\end{array}$ \\
\hline Large-scale consumers (e.g. CHP plants). & 1 & 9 & 3 & 0 & 3 & 0 \\
\hline Households. & 0 & 7 & 3 & 3 & 2 & 1 \\
\hline Traders. & 2 & 8 & 1 & 1 & 1 & 3 \\
\hline $\begin{array}{l}\text { Small producers (less than } 100000 \text { tons } \\
\text { capacity). }\end{array}$ & 1 & 4 & 3 & 4 & 1 & 3 \\
\hline $\begin{array}{l}\text { Large producers (over than } 100000 \text { tons } \\
\text { capacity). }\end{array}$ & 3 & 7 & 1 & 1 & 1 & 3 \\
\hline
\end{tabular}

Comments made in response to the questionnaire suggest that respondents feel that the Finnish wood pellet industry is more oriented to medium-scale and large power plants and that households have lower priority. Private customers are not very interested in wood pellets because wood pellets are not very competitive with other biofuels (Section 4.2.2).

Selkimäki et al. [32] suggest that a lack of subsidies to private households for changing to pellet heating systems make the investment cost of changing to a pellet heating system very high. Respondents to this survey suggest that small-scale users are not a priority for big wood pellets producers because they are not as profitable. Finland lacks promotion of quality small-scale wood pellet appliances, and there are no nationwide full service providers. Respondents observe: "Some small local companies have the know-how from installation to service but not enough." And: "The residential consumption is very low compared to other similar European countries, but district heating in different sizes is promising."

According to respondents, underdeveloped pellet transport systems have caused the poor reputation of pellet heating, especially for houses and smaller buildings under $500 \mathrm{~kW}$ heating power. The above- mentioned factor has caused very slow boiler market development and is considered as being the cause of negative experiences of users. However, according to respondents, increasing production by large producers seems possible. The information given in section 2 seems to support such claims.

\subsection{Future perspectives}

Respondents were asked how increasing Finnish domestic demand can be met in the next 5-10 years (Figure 7). In this question respondents could choose one or more options. Most respondents suggest that demand can be met by increasing Finnish wood pellet production and increasing imports from Russia. There are no remarkable differences between the opinions of the different respondent groups. The only main difference was that respondents from outside Finland suggest mostly importing pellets from other countries, while Finnish wood pellet producers suggest increasing domestic production. 


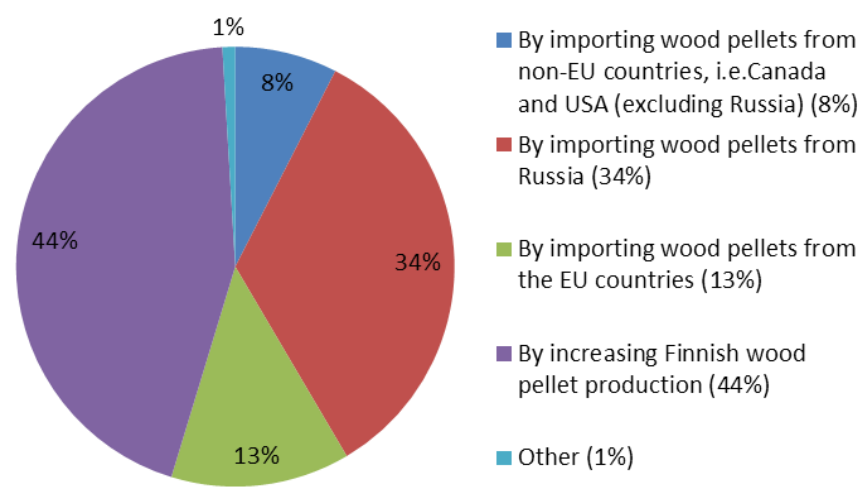

Figure 7: Responses to the question how Finnish domestic demand for wood pellets can be satisfied, during the next 5-10 years.

Most experts from the Finnish wood pellet industry believe that the prospects of the Finnish wood pellet industry seem very promising (Figure 8). In view of the target of increasing biomass consumption, the good availability of forest resources and innovations in combustion technology, this optimism about the future of the wood pellet industry in Finland does not seem misplaced. An interesting finding is that respondents whose location is outside Finland have a very optimistic view about the future of the Finnish wood pellet industry. $60 \%$ and $30 \%$ of such respondents expect growth or significant growth in the Finnish wood pellet industry, respectively. This finding seems to suggest that Finnish wood pellets have an attractive and solid reputation in other countries.

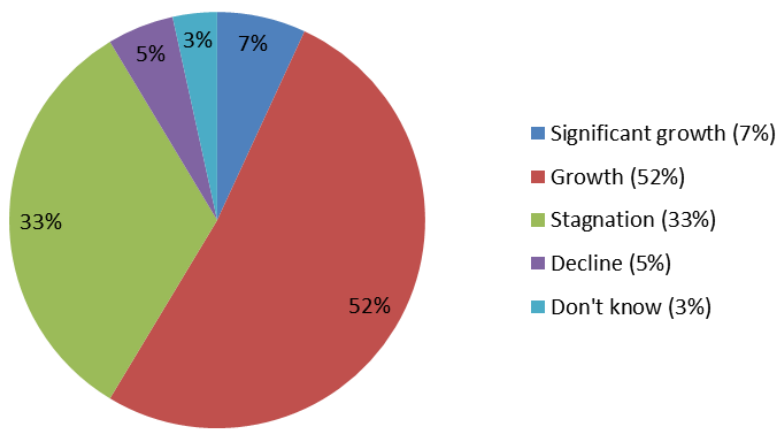

Figure 8: Opinions about future prospects of the Finnish wood pellet industry over the next 5-10 years (in \%).

Respondents from households using wood pellets are less optimistic; $63 \%$ of them expect stagnation and only $25 \%$ growth of the Finnish wood pellet industry. This can be explained by the low interest of households in wood pellet use for reasons mentioned in previous sections (section 2, 4.2.3 and 4.4). In the group of respondents with more than 10 years' experience in the wood pellet industry, more believe in growth of the Finnish wood pellet industry (47\%) than in stagnation (40\%). This can be a good sign as respondents with experience and knowledge can be considered to be better able to evaluate the current trajectory of the industry.

In summary, Finland has a good chance to become one of the leading countries on European wood pellet markets in terms of production and consumption. Considering international trade in wood pellets, large changes in export and import volumes of wood pellets are not foreseeable in the short- and medium-term. Finnish wood pellets producers are planning to increase capacity to satisfy local demand. 


\section{Conclusion}

Wood pellets are a very attractive biofuel due to their advantageous heating characteristics and ease with which they can be efficiently handled, stored, and transported compared with raw biomass. Consequently, wood pellets are becoming a promising and stable commodity on biomass markets. In the EU as a whole, there is a trend of greater development of wood pellets markets. In Finland, wood pellets are locally produced and dedicated to the domestic market. Although, the scale of the Finnish forest industry means good availability of raw material for wood pellet production, wood pellets play a relatively minor role in Finnish bioenergy. However, reaching the $100 \%$ renewables by 2050 requires the development of all possible options for biofuels, including wood pellets.

Based on the respondents' answers, it can be concluded that inadequate policy support and a lack of appropriate regulation, together with underinvestment and competition from other biofuels are the key factors inhibiting Finnish wood pellet industry development. However, due to the limitations of the survey method, for example, self-selection of the respondents and the possibility of expression of self-interest, these findings can only be considered as indicative.

When considering the results in more detail, the main obstacles to Finnish wood pellet industry development can be explained by low fossil fuel prices, competition from other solid biofuels such as wood chips, which have a long history of use in Finland, a lack of government actions supporting wood pellet use, and the high price of raw material, for which there are competing uses. The study further shows that the Finnish wood pellet industry is more oriented to mediumscale and large power plants, and households have lower priority. Private consumers tend not to be very interested in wood pellets, primarily because wood pellets are not very competitive with other biofuels. Thus, Finnish policy should pay more attention to motivation of wood pellet usage among households, and taxation policy, particularly regarding fossil fuel use, requires review.

Generally, the prospects for the wood pellet industry can be considered promising and wood pellets could have a more important role in the future Finnish energy mix. Wood pellets are environmentally friendly and local and European targets of increasing renewable energy are driving factors for increased utilization of wood pellets. The consumption of wood pellets is growing and may increase considerably in coming years, depending on factors such as policy regulation and investments, as well as reduced raw material prices and greater promotion of pellets.

The results of this study can be utilized by policy and decision makers in the wood pellet industry both within and outside Finland. Results are reliable and interesting not only for people directly involved in the Finnish wood pellet industry but also for researchers, industry analysts and other experts. The research method is applicable to countries with similar pellets market, such as countries in Central Europe. Future research should concentrate on the development of recommendations for policy to stimulate the Finnish wood pellet industry, in particular, policy measures to encourage Finnish households to switch from fossil fuel-based solutions to wood pellets, and how to improve the competitiveness of wood pellets.

\section{Acknowledgement}

The authors of the study gratefully acknowledge the time and effort put in by the wood pellet experts who responded to the questionnaire. Without their selfless support this research would not have been possible. The authors would like to thank Peter Jones (LUT) and Eija Alakangas (VTT) for valuable comments. The authors would like to acknowledge members of IEA Task 40 
"Sustainable International Bioenergy Trade - Securing Supply and Demand" for their insights into pellet market operation. 


\section{References}

[1] Energy Authority, http://www.energiavirasto.fi/web/energy-authority; 2016 [accessed 08.02.16].

[2] Child M, Breyer C. Vision and initial feasibility analysis of a recarbonised Finnish energy system for 2050. Renew Sustain Energy Revie 2016;66:517-536.

[3] Mathiesen BV, Lund H, Connolly D, Wenzel H, Østergaard PA, Möller B et al. Smart Energy Systems for coherent 100\% renewable energy and transport solutions. Applied Energy 2015;145:139-54.

[4] Lund H, Mathiesen BV. Energy system analysis of $100 \%$ renewable energy systems-The case of Denmark in years 2030 and 2050. Energy 2009;34(5):524-31.

[5] Milan C, Bojesen C, Nielsen MP. A cost optimization model for 100\% renewable residential energy supply systems. Energy 2012;48:118-27.

[6] Esteban M, Portugal-Pereira J. Post-disaster resilience of a 100\% renewable energy system in Japan. Energy 2014;68:756-64.

[7] Ćosić B, Krajačić G, Neven Duić N. A 100\% renewable energy system in the year 2050: The case of Macedonia. Energy 2012;48(1):80-7.

[8] Fernandes L, Ferreira P. Renewable energy scenarios in the Portuguese electricity system. Energy 2014;69:51-7.

[9] Olabi AG. 100\% sustainable energy. Energy 2014;77(1):1-5.

[10] Lestander TA. Pellet and briquette production. Chapter 13 in: Dahlquist E. Technologies for converting biomass to useful energy - combustion, gasification, pyrolysis, torrefaction and fermentation; 2013. p. 345-355.

[11] Sikkema R, Junginger M, Pichler W, Hayes S, Faaij APC. The international logistics of wood pellets for heating and power production in Europe: Costs, energy-input and greenhouse gas balances of pellet consumption in Italy, Sweden and the Netherlands. Biofuels, Bioprod. Bioref 2010;4:132-53.

[12] Proskurina S, Rimppi H, Heinimö J, Hansson J, Orlov A, KC R et al. Logistical, economic, environmental and regulatory conditions for future wood pellet transportation by sea to Europe: The case of Northwest Russian seaports. Renew Sustain Energy Rev 2016;56:38-50.

[13] Giacomo GD, Taglieri L. Renewable energy benefits with conversion of woody residues to pellets. Energy 2009;34:724-31.

[14] Uslu A, Faaij APC, Bergman PSA. Pre-treatment technologies, and their effect on international bioenergy supply chain logistics. Techno-economic evaluation of torrefaction, fast pyrolysis and pelletisation. Energy 2008;33:1206-23.

[15] Nishiguchi S, Tabata T. Assessment of social, economic, and environmental aspects of woody biomass energy utilization: Direct burning and wood pellets. Renewable and Sustainable Energy Reviews 2016;57:1279-86.

[16] Alakangas E, Hurskainen M, Laatikainen-Luntama J, Korhonen J. Properties of indigenouse fuels in Finland. VTT Technology 272; 2016. 222p.+app. 23 p.

[17] Trømborg E, Ranta T, Schweinle J, Solberg B, Skjevrak G, Tiffany DG. Economic sustainability for wood pellets production-A comparative study between Finland, Germany, Norway, Sweden and the US. Biomass and bioenergy 2013;57:68-77.

[18] Laschi A, Marchi E, González-García S. Environmental performance of wood pellets' production through life cycle analysis. Energy 2016;103(15):469-80. 
[19] Duca D, Riva G, Foppa Pedretti E, Toscano G. Wood pellet quality with respect to EN 14961-2 standard and certifications. Fuel 2014;135:9-14.

[20] Ståhl M, Wikström F. Swedish perspective on wood fuel pellets for household heating: A modified standard for pellets could reduce end-user problems. Biomass and bioenergy 2009;33:803-9.

[21] Alakangas E. Standardit kiinteille biopolttoaineille [Standards for solid biofuels], Bioenergia 2/2015, p. 11 [In Finnish], English flyer: International solid biofuels standards published available.

[22] Alakangas E. D5.2a. Case study of sustainable certified solid biomass supply chainKyyjärvi, Finland. 2013. 28p.

[23] Alakangas E. Solid wood fuel standardization and certification in EN/ISO, Bioenergy Forum, Japan, Tokyo, 3 March 2015. (oral presentation).

[24] Moiseyev A, Solberg B, Maarit A, Kallio L. The impact of subsidies and carbon pricing on the wood biomass use for energy in the EU. Energy 2014;76:161-67.

[25] AEBIOM, European biomass association. Statistical report. 2015. http://www.aebiom.org/library/statistical- reports/statistical-report-2015/ [accessed 16. 08.16].

[26] Argusmedia. News wood pellet and chip markets. Argus Biomass Markets No 15 (January through May); 2015.

[27] Sikkema R, Steiner M, Junginger M, Hiegl W, Hansen MT, Faaij A. The European wood pellet markets: current status and prospects for 2020. Biofuels, Bioprod. Bioref 2011;3:250-78.

[28] Kristöfel C, Strasser C, Schmid E, Morawetz UB. The wood pellet market in Austria: A structural market

model analysis. Energy policy 2016;88:402-12.

[29] Olsson O, Hillring B. The wood fuel market in Denmark-Price development, market efficiency and

internationalization. Energy 2014;48:141-48.

[30] Pelletsatlas. Pellet market country report Finland, http://pelletsatlas.info/pelletsatlas_docs/showdoc.asp?id=091022154421\&type=doc\&pdf=true;

2009 [accessed 08.08.14].

[31] Zakeri B, Syri S, Rinne S. Higher renewable energy integration into the existing energy system of Finland - Is there any maximum limit? Energy 2015;92(3): 244-59.

[32] Proskurina S, Heinimö J, Mikkilä M, Vakkilainen E. The wood pellet business in Russia with the role of North- West Russian regions: present trends and future challenges. Renew Sustain Energy Rev 2015;51:730-40.

[33] Mola-Yudego B. Spatial analysis of the wood pellet production for energy in Europe. Renewable Energy 2014;63:76-83.

[34] Selkimäki M, Mola-Yudego B, Röser D, Prinz R, Sikanen L. Present and future trends in pellet markets, raw materials, and supply logistics in Sweden and Finland. Renewable and Sustainable Energy Reviews 2010;14(9):3068-75.

[35] Judl J, Koskela S, Korpela T, Karvsenoja N, Häyrinen A, Rantsi J. Net environmental impacts of low-share wood pellet co-combustion in an existing coal-fired CHP (combined heat and power) production in Helsinki, Finland. Energy 2014;77:844-51.

[36] Heinimö J, Ojanen V, Kässi T. Views on the international market for energy biomass in 2020: Results from a scenario study. International Journal of Energy Sector Management 2008;2:547-69. 
[37] den Herder M, Kolström M, Lindner M, Suominen T, Tuomasjukka D, Pekkanen M. Sustainability impact assessment on the production and use of different wood and fossil fuels employed for energy production in North Karelia, Finland. Energies 2012 5:4870-91.

[38] Alakangas A, Paju P. 2002. Wood pellets in Finland technology, economy, and market, http://www.ateap.cz/new/Pelety_Finsko.pdf; 2002 [accessed 18.08.14].

[39] Heinimö J, Alakangas E. Market of biomass fuels in Finland - an overview 2009. IEA Bioenergy Task 40 and EUBIONET III - Country report of Finland 2011, http://www.bioenergytrade.org/downloads/iea-task-40-country-report-2011-finland.pdf; 2011 [accessed 08.09.14].

[40] Luke. Puupelletit 2014, http://stat.luke.fi/puupelletit; 2015 [accessed 08.12.15].

[41] Luke. Natural Resources Institute Finland, Forest resource estimates by municipalities, http://www.metla.fi/ohjelma/vmi/vmi-moni-en.htm; 2014 [accessed 08.02.15].

[42] Karhunen A, Ranta T, Heinimö J, Alakangas E. Market of biomass fuels in Finland - an overview 2013. IEA Bioenergy Task 40 - Country report of Finland 2014.

[43] VAPO. We act responsibly-employ locally, http://www.vapo.fi/filebank/1892VAPO2014_UK_secured.pdf; 2014 [accessed 08.12.14].

[44] Proskurina S, Heinimö J, Mikkilä M, Vakkilainen E. The Finnish Wood Pellet Business. In: 23nd European Biomass Conference and Exhibition. 2015. Vienna, Austria.

[45] Statistics Finland's PX-Web databases. PX-Web Statfin in English > Energy > Energy supply and consumption $\gg$ Energyimport and export by country. http://pxweb2.stat.fi/database/StatFin/databasetree_en.asp; 2016 [accessed 18.03.16].

[46] Helen. Helsingin Energia and Vapo agree on Finland's largest pellet deliveries 2014, https://www.helen.fi/en/News/2014/helsingin-energia-and-vapo-agree-on-finlands-largest-pelletdeliveries/; 2014 [accessed 08.12.14].

[47] VTT. Technical research centre of Finland Ltd, http://www.vtt.fi/; [accessed 08.12.15].

[48] Finnish Bioenergy Association, http://www.bioenergia.fi/English; 2015 [accessed 08.12.15].

[49] Karhunen A, Laihanen M, Ranta T. The role of local renewable energy sources in regional energy production, case South-East Finland. In: 22nd European Biomass Conference and Exhibition. 2014. Hamburg, Germany.

[50] Finland's National Forest Programme 2015 (3b/2008), http://www.mmm.fi; [accessed 08.02.15].

[51] Anttila P, Nivala M, Laitila J, Flyktman M, Salminen O, Nivala J. Metsähakkeen alueellinen korjuupotentiaali ja käyttö vuonna 2020. Metla työraportteja 313. 55 s. 2014.

[52] Nardi PM. Doing survey research. A guide to quantitative methods 3rd edition. Paradigm Publishers, USA. 2014.

[53] AEBIOM. Statistical Report - European Bioenergy Outlook, http://www.aebiom.org/library/statistical- $\quad$ reports/statistical-report-2015/; $2015 \quad$ [accessed 18.11.15].

[54] Linden M. Forecasting forest chip energy production in Finland 2008-2014. Biomass and Bioenergy 2011;35(1):590-99.

[55] Kärhä K. Industrial supply chains and production machinery of forest chips in Finland. Biomass and Bioenergy 2011;35(8):3404-13.

[56] Finnish Environment Institute, (Suomen ympäristökeskus), Peat production decreasing in Finland, http://www.ymparisto.fi/en-

US/Maps_and_statistics/The_state_of_the_environment_indicators/Natural_resources/Peat_prod uction_decreasing_in_Finland\%2828239\%29;2015 [accessed 08.12.15]. 
[57] Proskurina S, Sikkema R, Heinimö J, Vakkilainen E. Five years left-How are the EU member states contributing to the $20 \%$ target for EU's renewable energy consumption; the role of woody biomass. Biomass and bioenergy 2016;95:64-77.

[58] Ericsson K, Huttunen S, Nilsson LJ, Svenningsson P. Bioenergy policy and market development in Finland andSweden. Energy Policy 2004;32:1704-21.

[59] NREAP. National renewable energy action plans. Finland, http://ec.europa.eu/energy/renewables/action_plan_en.ht; 2009 [accessed 08.10.14].

[60] Finnish Bioeconomy Strategy, http://www.tem.fi/files/40366/The_Finnish_Bioeconomy_Strategy.pdf; 2014 [accessed 28.08.15]. 